\title{
Krąg rodzinny ks. Andrzeja Chylińskiego (1799-1862), proboszcza parafii Męka w dekanacie sieradzkim
}

\section{Abstract \\ The family circle of Fr. Andrzej Chyliński (1799-1862), Męka parish priest in the Sieradz deanery}

\begin{abstract}
fter his studies at the seminary in Włocławek, Andrzej Chyliński, born A in 1799, was ordained a priest in 1823. He was initially a vicar in Mstów, then an administrator in Przystajń, Wilkowiecko, Mierzyn, and Wola Grzymalina. In the years 1833-1843, he served in Wasosz, and in the years 1843 to $1862-$ that is until his death - he was an administrator and parish priest in Męka in the Kujawsko-Kaliska diocese. He was born in a family of craftspeople and came from a small private town of Lubraniec near Włocławek. After his father's death, Andrzej Chyliński's family, who he undoubtedly supported, lived in the priest's pastoral institutions. The clergyman's position influenced the marriages of his sisters. A certain accumulation of capital, which was possible thanks to the brother's work, was perhaps useful for the dowry. The priest's brothers-in-law were the son of a clerk - probably an impoverished nobleman - and the son of townspeople from Kielce. The social circle of the priest's relatives consisted of representatives of the local nobility, intelligentsia, low-level officials, skilled workmen, as well as local peasants. In order to match the yeomanry environment, the clergyman tried to raise the social status of his loved ones in various acts and deeds by calling them "born". The desire to establish the current position and to obliterate the petty-bourgeoisie origin should be associated with interference in the content of the metric records of the priest's siblings, in which bourgeois qualifiers such as "honest" and "notorious" were removed and replaced by the term "Sir".
\end{abstract}

Keywords: genealogy, biographical writing, social promotion, Lubraniec, Męka, lower middle class, clergy, $19^{\text {th }}$ century 
STRESZCZENIE

U rodzony w 1799 r. Andrzej Chyliński, po nauce w seminarium we Włocławku, został w 1823 r. wyświęcony na księdza. Był początkowo wikariuszem w Mstowie, następnie administratorem w Przystajni, Wilkowiecku, Mierzynie, Woli Grzymalinie, w latach 1833-1843 w Wąsoszu, a w latach 1843-1862 administratorem i proboszczem parafii Męka w diecezji kujawsko-kaliskiej. Pochodził z rodziny rzemieślniczej, $z$ małego prywatnego miasta Lubraniec pod Włocławkiem. Po śmierci ojca na placówkach duszpasterskich księdza mieszkała jego rodzina, którą niewątpliwie utrzymywał. Pozycja duchownego wpłynęła na mariaże jego sióstr. Pewna akumulacja kapitału, która nastapiła dzięki pracy brata, zapewne przydała się na posag. Szwagrami kapłana zostali: syn urzędnika - zapewne zubożałego szlachcica oraz syn mieszczan z Kielc. Krąg towarzyski krewnych księdza składał się z przedstawicieli lokalnej szlachty, inteligencji, urzędników niskiego szczebla, fachowców, jak też okolicznych chłopów. By dorównać drobnoszlacheckiemu otoczeniu, duchowny starał się podnieść status społeczny bliskich, w aktach określając ich mianem „urodzonych”. $Z$ chęcią ugruntowania aktualnej pozycji i zatarcia drobnomieszczańskiego pochodzenia należy wiązać ingerencję w treść zapisów metrykalnych rodzeństwa księdza, w których usunięto kwalifikatory mieszczańskie „uczciwy” i „sławetny”, zastępując je określnikiem „pan”.

Słowa kluczowe: genealogia, biografistyka, awans społeczny, Lubraniec, Męka, drobnomieszczaństwo, duchowieństwo, XIX w.

\section{Wstęp}

S

zersze analizy prozopograficzne duchowieństwa katolickiego wymagają jednostkowych, szczegółowych badań biograficznych $z$ wykorzystaniem źródeł umożliwiających odtworzenie pochodzenia kapłana ${ }^{1}$. W nurt tych rozważań wpisuje się również niniejsza praca, która stanowi próbę rekonstrukcji powiązań rodzinnych przedstawiciela duchowieństwa parafialnego w diecezji kujawsko-kaliskiej.

Celem artykułu jest przedstawienie pochodzenia i najbliższej rodziny ks. Andrzeja Chylińskiego. W tekście omówiono wpływ kariery i prestiżu duchownego na losy jego rodzeństwa. Pozycja księdza ułatwiła awans jego krewnych. Powstałe w otoczeniu kapłana kontakty towarzyskie wpłynęły bowiem na decyzje matrymonialne jego sióstr. Zaprezentowano również sposoby zatarcia pierwotnie niższego pochodzenia społecznego rodziny.

${ }^{1}$ Por. np. K. Lewalski, Odsłony codzienności. Rzymskokatolickie duchowieństwo parafialne na prowincji Królestwa Polskiego na przełomie XIX i XX wieku. Wybrane zagadnienia, Gdańsk 2019. 
Tytułowego bohatera artykułu, Andrzeja Chylińskiego można uznać za reprezentanta duchowieństwa administrującego względnie dużymi parafiami wiejskimi. Jako kanonik honorowy wyróżniał się też na tle księży dekanatu, w większości niemających dystynktorium ${ }^{2}$.

\section{Posługa kapłańska}

Andrzej Chyliński urodził się w 1799 r. Naukę w seminarium we Włocławku rozpoczał w roku $1819^{3}$. Święcenia kapłańskie przyjał w 1823 r. ${ }^{4}$ Następnie spełniał posługę kapłańską na południowym krańcu diecezji kujawsko-kaliskiej w dekanacie częstochowskim w parafii Mstów. Później był komendarzem ${ }^{5}$ w parafii Przystajń $(1828-1830)^{6} \mathrm{w}$ ościennym dekanacie krzepickim i w Wilkowiecku $(1830-1832)^{7}$, ponownie w dekanacie częstochowskim. Następnie był duszpasterzem w Mierzynie w dekanacie piotrkowskim, później administratorem parafii Wola Grzymalina w dekanacie brzeźnickim. W następnej kolejności (w latach 1833-1843) A. Chyliński administrował parafia Wąsosz w dekanacie krzepickim ${ }^{8}$. Ostatecznie opuścił południowe rubieże diecezji. Druga połowa okresu jego pracy kapłańskiej przypada na już trwały pobyt w okolicach jej centralnej części. W latach 1843-1862 pełnił funkcję administratora i proboszcza parafii Męka9 . W tym czasie został kanonikiem honorowym kaliskim.

${ }^{2}$ W składającym się z 15 parafii dekanacie sieradzkim jedynie pięć parafii (w tym Męka) miało ponad 2000 wiernych. Por. Ordo divini offici ad usum dioecesis Vladislaviensis seu Calissiensis pro anno domini 1862..., Warszawa [1861], s. 19-20.

${ }^{3}$ Ordo divini offici ad usum universi cleri saecularis dioecesis Vladislaviensis seu Calissiensis pro anno bissextili MDCCCXX..., Warszawa [1819], s. 8.

${ }^{4}$ S. Zabraniak, Między Warta a Liswarta.. Z dziejów parafii Wassosz (do 2015 r.), Częstochowa 2015, s. 133.

${ }^{5}$ Komendarz - duchowny, który otrzymał komendę, tymczasowy administrator pełniacy obowiazki parafialne na wakujacym probostwie. Por. Encyklopedja kościelna podług teologicznej encyklopedji Wetzera $i$ Weltego z licznemi jej dopełnieniami przy wspótpracownictwie kilkunastu duchownych $i$ swieckich osób, wyd. M. Nowodworski, t. X, Warszawa 1877, s. 542-543.

${ }^{6}$ W.P. Wlaźlak, Parafia Przenajświętszej Trójcy $w$ Przystajni, „Rocznik Towarzystwa Genealogicznego Ziemi Częstochowskiej” 2015-2016, t. VII-VIII, s. 101.

7 Idem, Parafia św. Mikołaja Biskupa $i$ Wyznawcy $w$ Wilkowiecku, ibidem, s. 127 .

8 S. Zabraniak, op. cit., s. 133.

${ }^{9}$ W. Kujaws ki, Kościelne dzieje Sieradza, Włocławek 1998, s. 164. 


\section{Miejsce pochodzenia}

Położone około $20 \mathrm{~km}$ na południowy zachód od Włocławka prywatne miasto szlacheckie Lubraniec ${ }^{10} \mathrm{w}$ wieku XIX „było biedne i źle zabudowane". Mieszkańcy trudnili się głównie szewstwem. W 1827 r. w 149 domach było łącznie z Żydami 1906 mieszkańców ${ }^{11}$. W 1806 r. założono tu na nowo szkołę, w której w 1816 r. uczyło się 96 uczniów $^{12}$. Dla dzieci rzemieślników była to szansa na zdobycie podstawowej edukacji, z czego rodzina A. Chylińskiego zapewne skorzystała, co sugeruja autografy jego rodzeństwa.

Andrzej Chyliński przyszedł na świat 23 listopada 1799 r. w Lubrańcu. Chrzest przyjął kolejnego dnia. Jego rodzicami chrzestnymi zostali "sławetny"13 Walenty Gniewecki, kawaler, i Rozalia Zychowska $z$ Lubrańca ${ }^{14}$. Najprawdopodobniej był przedślubnym dzieckiem swych rodziców, którzy zawarli małżeństwo dwa i pół miesiąca później. Kawaler Jan Chyliński, liczący 26 lat, i panna Marianna Badowska, mająca 20 lat, pobrali się w Lubrańcu 10 lutego 1800 r., w obecności świadków Józefa Starnawskiego, Wojciecha Jankiewicza i Michała Zuchowskiego, mieszkańców Lubrańca ${ }^{15}$. Andrzej był zatem pierworodnym potomkiem swych rodziców. Młodsze rodzeństwo przyszło na świat w Lubrańcu w latach 1802-1820:

1) 11 lutego 1802 r. Julianna Marianna, która w dniu urodzin przyjęła chrzest, a jej rodzicami chrzestnymi zostali Michał Jankiewicz i Agnieszka Jankiewiczowa. W ceremonii asystowali Jakub Veyner ${ }^{16}$ i Agnieszka Jankiewiczowa, mieszkańcy Lubrańca ${ }^{17}$.

2) 1 stycznia 1805 r. Marianna, która 8 stycznia przyjęła chrzest, a jej rodzicami chrzestnymi zostali „uczciwi” Chrystian Szulc i Magdalena Adamczewska. W ceremonii asystowali „uczciwi” Wojciech Adamczewski oraz Magdalena Szulcowa, mieszkańcy Lubrańca ${ }^{18}$.

${ }^{10}$ W. Kubiak, Dzieje Lubrańca, Toruń 2005, s. 52-64.

11 S. Muznerows ki, Lubraniec (monografia), Włocławek 1910, s. 159.

12 Ibidem, s. 146-147.

13 Przy nazwiskach podano kwalifikatory stanowe: honestus - uczciwy, famatus - sławetny, dominus - pan, generosus - urodzony.

${ }^{14}$ Archiwum Diecezjalne we Włocławku [dalej: ADWł], sygn. KM par. Lubraniec 2 , s. 92.

15 ADWł, sygn. KM par. Lubraniec 24, s. 121.

${ }^{16}$ Lub Vegner.

17 ADWł, sygn. KM par. Lubraniec 2, s. 112.

18 ADWł, sygn. KM par. Lubraniec 2a, s. 15. 
3) 24 kwietnia 1806 r. Stanisław, który 5 maja przyją chrzest, a jego rodzicami chrzestnymi zostali „uczciwy” Wojciech Sobecki i Marianna Kuźnicka, mieszkańcy Lubrańca ${ }^{19}$.

4) 14 stycznia 1809 r. Marianna Franciszka, która 30 stycznia przyjęła chrzest, a jej rodzicami chrzestnymi zostali zamieszkały w Lubrańcu „sławetny” Jakub Kokorzycki, majster kunsztu szewskiego, niepiśmienny, liczący 40 lat, oraz Teodora Bogacka. W ceremonii asystowali Augustyn Bogacki, majster kunsztu rymarskiego, niepiśmienny, liczący 30 lat, oraz panna Magdalena Cichocka, mieszkańcy Lubrańca ${ }^{20}$.

5) 7 lub 8 maja 1811 r. ${ }^{21}$ Joanna Nepomucena Julianna, która 9 maja przyjęła chrzest, a jej rodzicami chrzestnymi zostali „pan” Walerian Łukasiewicz i Joanna Dorota Goetze, mieszkańcy Lubrańca ${ }^{22}$. Świadkami wymienionymi w akcie urodzenia byli niepiśmienni Łukasz Andrychowski, majster kunsztu stolarskiego, liczacy 40 lat, i Jan Siboroski, kościelny, liczący 60 lat, zamieszkali w Lubrańcu ${ }^{23}$.

6) 23 marca 1817 r. Salomea, która 7 kwietnia 1817 r. przyjęła chrzest, a jej rodzicami chrzestnymi zostali „pan” Wincenty Brański, sekretarz, i „sławetna” Rozalia Kucińska ${ }^{24}$.

7) 3 lub 28 marca 1820 r. ${ }^{25}$ Józef, który 29 września przyjął chrzest, a jego rodzicami chrzestnymi zostali „sławetny” Seweryn Płatkoski, rolnik, kawaler, niepiśmienny, liczący 26 lat, i Józefa Kręplewiczowa $^{26}$. Świadkiem wymienionym w akcie urodzenia był Tomasz Bednarowicz, szewc, niepiśmienny, liczący 45 lat, zamieszkały w Lubrańcu ${ }^{27}$.

19 Ibidem, s. 34.

20 ADWł, sygn. KM par. Lubraniec 2a, s. 67; Archiwum Państwowe w Toruniu Oddział we Włocławku [dalej: APToW], Akta Stanu Cywilnego [dalej: ASC] Lubraniec, sygn. 1, s. 24-25, nr 52.

${ }^{21}$ Różnica między data podaną w metryce chrztu i akcie stanu cywilnego urodzenia.

22 ADWł, sygn. KM par. Lubraniec 4, s. 18.

23 APToW, ASC Lubraniec, sygn. 9, nr 7.

${ }^{24}$ ADWł, sygn. KM par. Lubraniec 4, s. 99. Część zapisu metrykalnego tyczaca się zapewne daty urodzenia jest wytarta, stąd moga pojawić się wattpliwości, czy narodziny nastapiły w roku chrztu.

${ }^{25}$ Różnica między datą podaną w metryce chrztu i akcie stanu cywilnego urodzenia.

${ }^{26}$ ADWł, sygn. KM par. Lubraniec 4, s. 152.

27 APToW, ASC Lubraniec, sygn. 27, nr 85. 
Wśród chrzestnych i świadków dzieci Chylińskich dominują „uczciwi”, rzadziej „sławetni”; rzemieślnicy (szewcy, rymarz, stolarz), pojawia się rolnik, kościelny, będący mieszczanami z Lubrańca. $Z$ wyżej sytuowanego środowiska wywodził się jedynie sekretarz, zapewne lokalnego urzędu, określony jako „pan”. Świadkowie byli niepiśmienni, podobnie jak ojciec dzieci. Znany z metryk krąg osób świadczy o niewielkiej więzi towarzyskiej rodziny $z$ elitami miasteczka czy okolic. Rodzice duchownego $z$ pewnościa kontaktowali się $z$ krewnymi, którzy również przebywali w Lubrańcu.

W Lubrańcu mieszkali w tym czasie małżonkowie Andrzej i Katarzyna Chylińscy, mający podobne kontakty towarzyskie co Jan i Marianna Chylińscy. Możliwe, że przyszły ksiądz A. Chyliński był bratankiem swego starszego imiennika, „uczciwego” („sławetnego") Andrzeja Chylińskiego. Jego potomstwo przyszło na świat w Lubrańcu w latach 1801-1805:

1) 16 sierpnia 1801 r. Bartłomiej, który 17 sierpnia przyją chrzest, a jego rodzicami chrzestnymi zostali Michał Jankowski z Bielic i Katarzyna Markiewiczowa. W ceremonii asystowali Wojciech Sobecki i Franciszka Tomaszewska oraz Jan Krzeczewski i Petronella Krzymińska, mieszkańcy Lubrańca ${ }^{28}$.

2) 16 sierpnia 1803 r. Bartłomiej29, który 18 sierpnia przyjął chrzest, a jego rodzicami chrzestnymi zostali "sławetni” Antoni Popieliński i Marianna Koźmicka. W ceremonii asystowali „sławetny” Fran $[\ldots]^{30}$ Kuźmicki i Agnieszka Jankiewiczowa, mieszkańcy Lubrańca ${ }^{31}$.

3) 14 października 1805 r. Szymon, który 20 października przyjął chrzest, a jego rodzicami chrzestnymi zostali „sławetni” Fryderyk Weis[bremur], kawaler, i Franciszka Jankiewiczowa, mieszkańcy Lubrańca ${ }^{32}$.

Prawdopodobnie krewnym wyżej wymienionych Jana i Andrzeja Chylińskich (może bratankiem), a jednocześnie bratem stryjecznym duchownego był Łukasz Chyliński, syn Szymona i Magdaleny Chylińskich, urodzony około 1800 r., który pojawia się w Lubrańcu

\footnotetext{
${ }^{28}$ ADWł, sygn. KM par. Lubraniec 2, s. 107.

${ }^{29}$ Urodzony w druga rocznicę narodzin starszego brata, otrzymał jego imię.

${ }^{30}$ Zapewne Franciszek. Odczyt niepewny, uzupełnienie bądź rozwinięcie skrótu zamieszczono w nawiasie kwadratowym antykwą.

${ }^{31}$ ADWł, sygn. KM par. Lubraniec 2, s. 128.

${ }^{32}$ ADWl, sygn. KM par. Lubraniec 2a, s. 27.
} 
znacznie później. Dnia 9 kwietnia 1826 r. Ł. Chyliński jako kawaler, majster kunsztu kowalskiego, zamieszkały na Cegiełce pod Żydowem, w wieku 26 lat poślubił pannę Walentynę Kruszewską, licząca 16 lat, córkę Walentego i Małgorzaty Kruszewskich, zamieszkała $z$ rodzicami w Korzeszynku. Świadkami ślubu byli Andrzej Malinoski, owczarz, liczący 34 lata, oraz Kazimierz Lewicki, borowy, liczacy 50 lat, obaj zamieszkali w Żydowie. Akt podaje cenna informację dotyczacca miejsca urodzenia Łukasza, którym była wieś Koneck ${ }^{33}$ położona w okolicach Włocławka, skąd mogli się wywodzić Chylińscy. Gdy 25 stycznia 1828 r. zmarła w wieku dwóch lat w Korzeszynku ich córka Marianna, Łukasz i Walentyna Chylińscy zostali określeni jedynie jako „pracowici”34.

W metrykach początku XIX w. w Lubrańcu rzadko pojawia się nazwisko Badowski. W Lubrańcu 14 lipca 1816 r., w wieku 25 lat, panna Agnieszka Badowska poślubiła kawalera Stanisława Jendrzejowskiego, parobka, liczącego również 25 lat, zamieszkałego we wsi Krowicach. Status małżonka sugeruje równie ubogie pochodzenie jego wybranki. Wspomniana Agnieszka, córka Józefa i Agnieszki Badowskich, zamieszkała $z$ matka w Krowicach, urodziła się około 1791 r. w parafii Wieniec położonej w okolicach Włocławka ${ }^{35}$. Miejsce jej urodzenia również stanowi wskazówkę do poszukiwań krewnych w linii żeńskiej A. Chylińskiego.

Ojciec A. Chylińskiego Jan był jak wielu innych mieszkańców Lubrańca majstrem kunsztu szewskiego $(1809,1811,1820)$. Mieszkał w domu numer 20 (1809) i 84 (1811). Jego status społeczny był określany kwalifikatorem stanowym: „uczciwy” (1800, 1805, 1806, 1817) oraz „sławetny” (1802, 1809, 1820). Był zatem jako rzemieślnik przedstawicielem drobnomieszczaństwa. Jego nazwisko zapisywano też w formie Hyliński (1805) i Chyleński (1820). Jan Chyliński zmarł w Lubrańcu 4 czerwca 1828 r. w wieku 54 lat. Zgon zgłosił jego młodszy syn Stanisław oraz Jan Stankoski, liczący 41 lat, organista, obaj zamieszkali w Lubrańcu, określeni jako niepiśmienni ${ }^{36}$. Jan urodził się zatem około 1774 r., co potwierdza również metryka jego ślubu.

${ }^{33}$ ADWł, sygn. KM par. Lubraniec 14, nr 4.

${ }^{34}$ ADWł, sygn. KM par. Lubraniec 17, nr 15 s. 185.

35 APToW, ASC Lubraniec, sygn. 19, nr 4.

${ }^{36}$ ADWł, sygn. KM par. Lubraniec 19, nr 59, s. 100; ibidem, sygn. KM par. Lubraniec 17, nr 49, s. 187. 
Śmierć ojca zbiegła się w czasie z otrzymaniem przez A. Chylińskiego pierwszej parafii w administrację, co pozwoliło pierworodnemu przejąc obowiązki seniora rodu i zabezpieczyć byt materialny najbliższym. Przypuszczalnie rodzina przeniosła się wówczas do Przystajni koło Częstochowy, gdzie A. Chyliński został - jak wspomniano - komendarzem.

\section{Siostra Franciszka Cholewińska i jej potomstwo}

W Przystajni Franciszka mieszkała $z$ bratem A. Chylińskim, który pobłogosławił tam jej ślub 21 lutego 1830 r. Jej wybrankiem został liczacy 27 lat kawaler Leopold Cholewiński ${ }^{37}$, urodzony w Kielcach, zamieszkały w Pankach, syn Cyriaka i Józefy z Latosińskich Cholewińskich mieszkajacych w Kielcach. Nupturienci podpisali akt ślubu wraz ze świadkami, którymi byli liczacy 52 lata „wielmożny” Józef Szafrański, posesor wsi Przystajń, tamże zamieszkały, oraz liczacy 40 lat Franciszek Francke, kasjer, zamieszkały we wsi Panki ${ }^{38}$.

Pochodzacy $z$ okolicy L. Cholewiński został zapoznany niewątpliwie dzięki prestiżowi, jakim się cieszył lokalny administrator parafii. Franciszka osiadła wraz z mężem w pobliżu prebend brata. Przyszli tam na świat Cholewińscy, siostrzeńcy A. Chylińskiego. We wsi Panki w parafii Truskolasy urodzili się:

1) 18 grudnia 1830 r. Marian Edward Adam, który przyją chrzest 26 grudnia, a jego rodzicami chrzestnymi zostali „wielmożny" Edward Miączyński, wojewodzic, dziedzic wsi Miedzna, i „jaśnie wielmożna” Bogumiła Brzozowska sędzina, dziedziczka wsi Waleńczowa. Świadkami wymienionymi w akcie urodzenia byli niepiśmienni Franciszek Hyra, liczacy 50 lat, oraz Walenty Glinka, liczacy 32 lata, gospodarze zamieszkali w Pankach ${ }^{39}$.

2) 18 grudnia 1830 r. Marianna Apolonia, która przyjęła chrzest 26 grudnia, a jej rodzicami chrzestnymi zostali „wielmożny jegomość" ks. Adam Sadowski, dziekan częstochowski, proboszcz parafii Kłobuck, oraz „wielmożna jegomość pani” Apolonia Strzelecka, posesorka wsi Waleńczowa. Świadkami wymienionymi

\footnotetext{
${ }^{37}$ Nazwisko zapisywano również w formie Holewiński.

${ }_{38}$ Archiwum Archidiecezji Częstochowskiej [dalej: AACz], sygn. KM 1646, Akt ślubu nr 9 z 1830 r.

39 Archiwum Państwowe w Częstochowie [dalej: APCz], ASC Truskolasy, sygn. 72, Akt urodzenia nr 265.
} 
w akcie urodzenia byli niepiśmienni Franciszek Hyra, liczący 50 lat, oraz Walenty Glinka, liczacy 32 lata, gospodarze zamieszkali w Pankach ${ }^{40}$.

3) 8 marca 1832 r. Sabina Aleksandra, która przyjęła chrzest 30 września, a jej rodzicami chrzestnymi zostali „wielmożny” Aleksander Kołaczkowski oraz „jaśnie wielmożna” generałowa Konstancja Blumer ${ }^{41}$. Świadkami wymienionymi w akcie urodzenia byli piśmienni Tomasz Spalikowski, zastępca wójta gminy Panki, liczacy 32 lata, oraz Bogumił Vogtmann ${ }^{42}$, liczacy 42 lata, zamieszkali w Pankach ${ }^{43}$.

4) 14 kwietnia 1833 r. Jadwiga Waleria, która przyjęła chrzest $z$ wody 5 maja, a jej rodzicami chrzestnymi zostali Tomasz i Franciszka małżonkowie Spalikowscy. Świadkami wymienionymi w akcie urodzenia byli piśmienni Tomasz Spalikowski, zastępca wójta gminy Panki, liczacy 32 lata, oraz Karol Paciorkowski, liczacy 30 lat, właściciel „sołtystwa”, zamieszkali w Trukskolasach ${ }^{44}$.

5) 20 kwietnia 1835 r. Teofila Bronisława, która przyjęła chrzest w Wąsoszu 5 maja, a jej rodzicami chrzestnymi zostali wuj, ks. A. Chyliński i Sabina Grabowska. Świadkami wymienionymi w akcie urodzenia byli piśmienni Tomasz Spalikowski, nauczyciel, liczacy 37 lat, oraz Tomasz Kasperkiewicz, liczacy 26 lat, organista, zamieszkali w Trukskolasach ${ }^{45}$.

6) 11 września 1836 r. Kazimierz Tadeusz Jan, który przyją chrzest $z$ wody w Przystajni 19 września, a jego rodzicami chrzestnymi zostali Sebastian Tomziński oraz Marianna Kaliska. Świadkami wymienionymi w akcie urodzenia byli piśmienni Bogumił Vogtmann, budowniczy fabryk, liczaccy 46 lat, oraz Franciszek Ligęza, liczący 37 lat, nauczyciel szkoły, zamieszkali w Pankach ${ }^{46}$.

W 1838 r. Cholewińscy mieszkali we wsi Wassosz, a w 1839 r. $\mathrm{w}$ mieście Iwanowicach.

$40 \mathrm{APC}$, ASC Truskolasy, sygn. 72, Akt urodzenia nr 266.

${ }^{41}$ Konstancja Bonin-Sławianowska, córka Jana i Michaliny z Bielińskich, wdowa po generale Ignacym Aleksandrze O’Blumer (1773-1830), przeciwniku powstania listopadowego.

${ }^{42}$ Inne wersje nazwiska: Bogumił Fogtman, G[otlib] Voglmann.

${ }^{43} \mathrm{APC}$, ASC Truskolasy, sygn. 76, Akt urodzenia nr 159.

${ }^{44}$ APCz, ASC Truskolasy, sygn. 78, Akt urodzenia nr 96.

${ }^{45}$ APCz, ASC Truskolasy, sygn. 82, Akt urodzenia nr 243.

${ }^{46}$ APCz, ASC Truskolasy, sygn. 84, Akt urodzenia nr 250. 
7) W latach 1837-1840 przyszedł na swiat ich kolejny syn Jan ${ }^{47}$.

W parafii Konopiska we wsi Trzepizurach urodził się następnie:

8) 12 grudnia 1841 r. Władysław Tomasz, który przyjął chrzest 18 grudnia, a jego rodzicami chrzestnymi zostali Henryk Kaden, zawiadowca wielkiego pieca, i Marianna [V Calgier]. Świadkami wymienionymi w akcie urodzenia byli niepiśmienni Antoni Cierpiał, rolnik, liczacy 46 lat, i Grzegorz Kajas, wyrobnik, liczący 41 lat, zamieszkali we wsi Trzepizury ${ }^{48}$.

W parafii i mieście Kłobuck urodzili się najmłodsi Cholewińscy:

9) 5 sierpnia 1845 r. Emilia Aleksandra, która przyjęła chrzest 16 grudnia, a jej rodzicami chrzestnymi zostali Nepomucen Lewański, miejscowy wikariusz, i pani Eleonora Daleszyńska. W ceremonii asystowali Feliks Próchnicki i Józefa Majewska, zamieszkali w Kłobucku. Świadkami wymienionymi w akcie urodzenia byli niepiśmienni Marcin Sosmówski, liczący 55 lat, i Antoni Lupczyński, liczacy 21 lat, obywatele rolnicy, zamieszkali w Kłobucku ${ }^{49}$.

10) 8 września 1847 r. Marianna Józefa, która przyjęła chrzest 3 października, a jej rodzicami chrzestnymi zostali „pan” Tadeusz Kołaczkowski i panna Jadwiga Kołaczkowska, zamieszkali we wsi Kamyk. Świadkami wymienionymi w akcie urodzenia byli niepiśmienni Józef Karkutkiewicz, złotnik, liczacy 60 lat, i Piotr Lubczyński, rolnik, liczący 25 lat, zamieszkali w Kłobucku. W akcie zapisano, że dziecko chrzcił ks. Ignacy Jarnuszkiewicz, kanonik kaliski, proboszcz kłobucki ${ }^{50}$.

Pięć lat po narodzinach ostatniego dziecka małżonkowie Cholewińscy nadal mieszkali w Kłobucku. Urządzili wówczas śluby dwójce starszych dzieci. W Zadzimiu 17 października 1852 r. liczaca 19 lat Sabina, jako panna we wsi Ralewicach „we dworze w służbie zostajacca", poślubiła liczącego 26 lat kawalera Michała Nowackiego, „gorzelanego” we wsi Ralewicach „na służbie zostającego”, urodzonego we wsi Góra, syna Kazimierza Nowackiego, "gorzelanego” we wsi Stolcu, i zmarłej Józefy z Kowalskich. Nupturienci podpisali akt wraz ze świadkami, którymi byli Józef Chrzanowski, propinator, liczący 42 lata, oraz Józef Skrzypiński, „gorzelany”, liczacy 37 lat ${ }^{51}$.

47 Archiwum Państwowe w Łodzi - Oddział w Sieradzu [dalej: APŁoS], Akta notariusza J. Sikorskiego w Szadku, sygn. 8, nr 212 z 1862 r.

$48 \mathrm{AACz}$, sygn. KM 4639, Akt urodzenia nr 115 z $1841 \mathrm{r}$.

$49 \mathrm{AACz}$, sygn. KM 4716, Akt urodzenia nr 343 z 1845 r.

50 AACz, sygn. KM 4717, Akt urodzenia nr 196 z 1847 r.

51 Archiwum Państwowe w Łodzi [dalej: APŁ], ASC Zadzim, sygn. 68, Akt ślubu nr 18. 
W Wieluniu 18 lutego 1852 r. liczacy 21 lat Marian Cholewiński, jako kawaler zamieszkały w Wieluniu, poślubił Monikę Baranowska, licząca 20 lat, córką Józefa i Małgorzaty Baranowskich, urodzoną i zamieszkała w Wieluniu $z$ rodzicami. Nupturienci zawarli umowę przedślubna 1 lutego 1852 r. w domu ojca panny (numer 17). Podpisali akt ślubu wraz $z$ drugim świadkiem, Rudolfem Zazońskim, chirurgiem, liczaccym 31 lat, zamieszkałym w Wieluniu. Pierwszy świadek Andrzej Kluszczyński, obywatel, zamieszkały w Wieluniu, liczący 45 lat, był niepiśmienny ${ }^{52}$.

Wuj dzieci Cholewińskich A. Chyliński chrzcił i był chrzestnym siostrzeńca Teofila Bronisława w Wassoszu 5 maja 1835 r. oraz chrzcił Kazimierza Tadeusza Jana 19 września 1836 r. w Przystajni. Wśród chrzestnych i świadków Cholewińskich znajdują się przedstawiciele lokalnej szlachty i ziemiaństwa: posesorowie, dziedzice wsi, określani jako „jaśnie wielmożni”, „wielmożni”, z urzędniczymi koneksjami (wojewodzic, sędzina); właściciel „sołtystwa”; lokalna inteligencja - nauczyciele oraz urzędnicy niższego szczebla zastępcy wójta, kasjer; fachowcy - budowniczy fabryk, zawiadowca wielkiego pieca, złotnik oraz duchowni - dziekan, administrator, wikariusz; organista oraz osoba $z$ wyższej sfery towarzyskiej, generałowa Konstancja Blumer. Świadkami zaś byli też niepiśmienni chłopi: gospodarze, rolnik, wyrobnik, obywatele-rolnicy, mieszczanie jako osoby w większym stopniu przypadkowe niż starannie dobrani chrzestni. Krag towarzyski siostry księdza składał się zatem głównie $z$ przedstawicieli lokalnych elit, co poza pozycja brata należało też wiązać $z$ relacjami wynikajacymi $z$ posad jej męża.

Szwagier A. Chylińskiego, Leopold Cholewiński występuje jako „urodzony” w latach 1830, 1833, 1838; „jegomość pan”, urzędnik w górnictwie krajowym w 1829 r. ${ }^{53}$, magazynier Hut Żelaznych Rządowych Pankowskich w 1830 r.; magazynier dozorstwa Pankowskiego w 1833 r.; archiwista Komisji Wojewódzkiej Województwa Kaliskiego w 1835 r.; zastępca wójta gminy Panki w 1836 r.; były zastępca wójta gminy Panki w 1838 r.; były urzędnik górniczy w 1841 r. i 1845 r.; „z własnych funduszów się utrzymujący” w 1847 r.; wójt gminy Kiedrzyn w 1852 r. Spośród wymienionych pozyskanie stanowiska archiwisty było zapewne największym osiągnięciem L. Cholewińskiego.

${ }^{52}$ APŁ, ASC Wieluń, sygn. 110, Akt ślubu nr 13.

${ }^{53}$ APCz, ASC Przystajń, sygn. 59, k. 12. 


\section{Siostra Salomea Walewska i jej potomstwo}

Na plebanii w Wąsoszu A. Chyliński w 1833 r. zamieszkał z rodzeństwem Stanisławem i Salomeą ${ }^{54}$ oraz matką. Młodszy brat mógł pomagać duchownemu w prowadzeniu kancelarii. Pięć lat później A. Chyliński pobłogosławił ślub wspomnianej młodszej siostry. W Wassoszu 14 listopada 1838 r. 21-letnia Salomea, jako panna, poślubiła liczącego 18 lat kawalera Tadeusza Łukasza Walewskiego, urodzonego i zamieszkałego w Wassoszu. Wybranek był synem nieżyjącego już wówczas Antoniego Walewskiego, podsędka powiatu radomskiego, i Ewy z Załuskich. Nupturienci podpisali akt wraz z A. Chylińskim, matka pana młodego, świadkami, którymi byli „wielmożny” Wojciech Janiszewski, dzierżawca wsi rządowej Wasosz, liczacy 51 lat, oraz L. Cholewiński ${ }^{55}$. Salomea była starsza od T. Walewskiego o trzy lata. Miejsce pracy i status brata wpłynęły na ożenek Salomei z pochodzacym $z$ zapewne dość dobrego domu kawalerem. Nazwisko i urzą ojca pana młodego sugeruja pochodzenie szlacheckie. Możliwe, że na szybką decyzję 18-letniego kawalera wpłynął odpowiedni posag panny młodej, dotąd będącej niewątpliwie na utrzymaniu brata. Początkowo Salomea osiadła wraz $z$ mężem w parafii brata, gdzie we wsi Wąsosz przyszła na świat pierworodna córka:

1) 14 sierpnia 1839 r. Konstancja Waleria, która przyjęła chrzest 16 sierpnia, a jej rodzicami chrzestnymi zostali Andrzej Zabłocki i ciotka dziecka Franciszka Cholewińska $z$ Iwanowic. Świadkami wymienionymi w akcie urodzenia byli wspomniany Andrzej Zabłocki, nauczyciel szkoły elementarnej w Wassoszu, liczacy 37 lat, oraz Józef Idzikowski, organista, liczący 21 lat, zamieszkali w Wąsoszu. Tadeusz Walewski, A. Zabłocki podpisali akt wraz z A. Chylińskim, który ochrzcił siostrzenicę ${ }^{56}$.

Następnie, być może w związku z poszukiwaniem pracy, Walewscy się przeprowadzili ${ }^{57}$. W 1846 r. mieszkali w parafii Truskolasy, gdzie poprzednio (w latach 1830-1836) przebywali Cholewińscy. We wsi Truskolasy urodziły się Walewskim kolejne dzieci:

${ }^{54}$ S. Zabraniak, op. cit., s. 213.

55 APCz, ASC Wassosz, sygn. 53, Akt ślubu nr 13.

56 APCz, ASC Wassosz, sygn. 54, Akt urodzenia nr 38.

$57 \mathrm{Z}$ okresu $\mathrm{z}$ pięciu lat brak danych dotyczących potomstwa Walewskich, stąd jest ono zapewne niekompletne. 
2) 12 marca 1846 r. Leon Teodor, który przyjął chrzest 30 sierpnia, a jego rodzicami chrzestnymi zostali Feliks Zagórowski i Karolina Kasinowska, w asystencji Józefy Zagórowskiej i Michała Kasinowskiego. Świadkami wymienionymi w akcie urodzenia byli Szymon Młynczyk, liczacy 42 lata, i Jakub Pacierpnik, liczacy 38 lat, gospodarze zamieszkali w Truskolasach ${ }^{58}$. Następnie Walewscy przeprowadzili się na północny zachód w okolice Wieruszowa do parafii Czastary, gdzie w osadzie Ławki rodziły się ich kolejne dzieci:

3) 13 maja 1848 r. Teodozja, która przyjęła chrzest 20 maja, a jej rodzicami chrzestnymi zostali Feliks Tomaszewski, podleśny, i Marianna Michalska, panna $z$ Przywar. Świadkami wymienionymi w akcie urodzenia byli niepiśmienni Józef Siwek ${ }^{59}$, liczący 35 lat, i Józef Forman, liczący 40 lat, gospodarze zamieszkali we wsi Krajanki ${ }^{60}$.

4) 29 maja 1850 r. Marianna, która przyjęła chrzest 30 maja, a jej rodzicami chrzestnymi zostali Jan i Teresa Bidzińscy z Wieruszowa. Świadkami wymienionymi w akcie urodzenia byli niepiśmienni Andrzej Lipieta, liczący 40 lat, i Błażej Naciskała, liczący 45 lat, gospodarze zamieszkali we wsi Czastary ${ }^{61}$.

5) 28 lutego 1852 r. Aleksander Roman, który przyją chrzest 29 lutego, a jego rodzicami chrzestnymi zostali Jan Kozłowski $z$ Wróblewa i Wiktoria Michalska. Świadkami wymienionymi w akcie urodzenia byli niepiśmienni Jan Preder, liczacy 40 lat, i Marceli Płószka, liczący 23 lata, gospodarze zamieszkali we wsi Czastary ${ }^{62}$.

6) 1 czerwca 1854 r. Antonina Paulina, która przyjęła chrzest 8 czerwca, a jej rodzicami chrzestnymi zostali Franciszek Czaykowski i Józefa Czaykowska. Świadkami wymienionymi w akcie urodzenia byli niepiśmienni Józef Siwek, liczacy 35 lat, i Tomasz Dudek, liczacy 50 lat, gospodarze zamieszkali we wsi Krajanki ${ }^{63}$.

7) 25 kwietnia 1857 r. Nepomucena Joanna, która przyjęła chrzest 20 maja, a jej rodzicami chrzestnymi zostali Jana Michalski i panna Anna Michalska $z$ wsi Czastary. Świadkami wymienionymi

\footnotetext{
58 APCz, ASC Truskolasy, sygn. 104, Akt urodzenia nr 131.

59 Nazwisko zapisano również w formie Siwik.

60 APŁ, ASC Czastary, sygn. 90, Akt urodzenia nr 15.

61 APE, ASC Czastary, sygn. 93, Akt urodzenia nr 17.

62 APE, ASC Czastary, sygn. 95, Akt urodzenia nr 12.

63 APŁ, ASC Czastary, sygn. 98, Akt urodzenia nr 48.
} 
w akcie urodzenia byli wspomniani Jan Michalski, wójt gminy Czastary, liczaccy 53 lat, i niepiśmienny Franciszek Duda, gospodarz czynszowy, liczacy 52 lata $^{64}$.

8) 21 stycznia 1859 r. we wsi Czastary Agnieszka, która przyjęła chrzest 28 stycznia, a jej rodzicami chrzestnymi zostali Ignacy Michalski i Joanna Bęczkowska. Świadkami wymienionymi w akcie urodzenia byli niepiśmienni Jan Grzegza, liczący 56 lat, i Wojciech Galiński, liczący 48 lat, czynszownicy zamieszkali we wsi Czastary ${ }^{65}$.

9) 4 lipca 1861 r. we wsi Czastary Emilia Felicjanna, która przyjęła chrzest 7 lipca, a jej rodzicami chrzestnymi zostali Kazimierz Michalski i Marianna Michalska. Świadkami wymienionymi w akcie urodzenia byli niepiśmienni Fabian Ochendzan, gospodarz, liczacy 46 lat, zamieszkały we wsi Przywary, i Walenty Siwek, gospodarz, liczacy 43 lata, zamieszkały we wsi Czastary ${ }^{66}$.

Mimo że Walewscy mogli pochodzić z zubożałej szlachty, Antoni i jego syn Tadeusz nie zostali odnotowani wśród legitymowanej szlachty ${ }^{67}$. Walewscy nie dbali o odpowiednia asystę podczas najważniejszych wydarzeń rodzinnych, stąd ich krag towarzyski przedstawia się dużo skromniej niż Cholewińskich. Wśród świadków początkowo występują „wielmożny” i dzierżawca wsi oraz nauczyciel. Po oddaleniu się małżonków od rezydencji brata-duchownego status świadków/chrzestnych jest niższy. Pojawiaja się wśród nich: wójt gminy, organista, zapewne współpracownik podleśny, ale przede wszystkim w większości okoliczni chłopi, niepiśmienni gospodarze, czynszownicy, zwłaszcza że T. Walewski sam nim został.

${ }^{64}$ APŁ, ASC Czastary, sygn. 102, Akt urodzenia nr 21.

65 APE, ASC Czastary, sygn. 105, Akt urodzenia nr 4.

66 APŁ, ASC Czastary, sygn. 109, Akt urodzenia nr 53.

67 Spis szlachty Królestwa Polskiego $z$ dodaniem krótkiej informacyi o dowodach szlachectwa, Warszawa 1851, s. 264-265; Szlachta wylegitymowana w Królestwie Polskim w latach 1836-1861, oprac. E. Sęczys, Warszawa 2000, s. 739-741. Nie występuja w herbarzu: Złota księga szlachty polskiej, oprac. T. Żychliński, R. I, Poznań 1879, s. 343-346; ibidem, R. II, Poznań 1880, s. 408; ibidem, R. III, Poznań 1881, s. 301-302; ibidem, R. IV, Poznań 1882, s. 402-409; ibidem, R. V, Poznań 1883, s. 377-380. Nie wymienia ich też M. Kobierecki, Walewscy herbu Kolumna w XVII-XVIII wieku. Genealogia. Majętności. Działalność publiczna, Łódź 2008, s. 350-354. 
Występuje on jako „urodzony” w 1838 i 1839 r.; podsędkiewicz w 1839 r.; strażnik lasów rządowych w 1846 i 1848 r.; strażnik celny graniczny w 1850 r.; sekwestrator skarbowy w 1852 r.; posiadacz osady leśnej Ławki w 1854 r.; cząstk[owy] dzierżawca „posady” leśnej Ławki należącej do Czastar w 1857 r.; czynszownik we wsi Czastary w 1859 r.; osadnik z Ławek w 1861 r.; właściciel osady w Czastarach w 1862 r. ${ }^{68}$

W latach czterdziestych i pięćdziesiątych XIX w., zapewne po uzyskaniu finansowej samodzielności, drogi rodzeństwa się rozchodzą. Andrzej Chyliński osiadł w Męce, Cholewińscy pozostali w Kłobucku (około $80 \mathrm{~km}$ w linii prostej od Męki), nieco bliżej, w Czastarach (około $50 \mathrm{~km}$ w linii prostej od Męki) zamieszkali Walewscy.

\section{Matka i brat Stanisław}

Na ostatniej placówce w Męce A. Chyliński mieszkał z matką. Andrzej Chyliński zmarł tam 17 czerwca 1862 r. w wieku, jak podaje akt zgonu, 63 lat $^{69}$, choć według ukończonych liczył 62 lata. Świadkami wymienionymi w akcie zgonu byli Jakub Nowakowski, organista $z$ Męki, liczący 53 lata, i Walenty Pawlik, rolnik z Męki, liczacy 50 lat. Śmierć matki 19 czerwca 1862 r. w Męce, zaledwie dwa dni po zgonie syna, zapewne nie była przypadkowa. Marianna Chylińska zmarła jako wdowa w wieku, jak podaje akt zgonu, 80 lat, choć według aktu ślubu mogła dożyć 82 lat. Świadkami wymienionymi w akcie jej zgonu byli niepiśmienni Franciszek Wegnorowski, kościelny z Męki, liczący 30 lat, i Walenty Pawlik, rolnik z Męki, liczący 50 lat. Niestety zabrakło osoby, która mogłaby podać spisującemu akt zgonu bliższe informacje o pochodzeniu zmarłej ${ }^{70}$.

Brat zmarłego Stanisław Chyliński był już w tym czasie (1862) właścicielem osady we wsi Janiszewice ${ }^{71}$. Dopiero jednak po śmierci księdza, licząc już 54 lata, zdecydował się na ślub. W Zduńskiej Woli 25 maja 1863 r. poślubił licząca 19 lat pannę Franciszka Szippel, córkę tkaczy Ferdynanda i Julianny z Janowskich małżonków Szippel, urodzoną i zamieszkałą z rodzicami w Zduńskiej Woli.

\footnotetext{
${ }^{68}$ APŁoS, Akta notariusza J. Sikorskiego w Szadku, sygn. 8, nr 212 z 1862 r.

69 APŁ, ASC Męka, sygn. 112, Akt zgonu nr 43.

70 Ibidem, Akt zgonu nr 44.

${ }^{71}$ APŁoS, Akta notariusza J. Sikorskiego w Szadku, sygn. 8, nr 212 z 1862 r.
} 
Nupturienci zawarli dwa dni wcześniej, 23 maja 1863 r. intercyzę przed notariuszem szadkowskim J. Zborowskim. Świadkami ślubu byli obywatele zamieszkali w Zduńskiej Woli, Józef Wilczyński, liczacy 45 lat, i Augustyn Michalski, liczaccy 55 lat. Wybranka była bardzo młoda i niepiśmienna. Stanisławowi Chylińskiemu zapewne wystarczały lokalne więzi $z$ napływowymi rzemieślnikami, bo i on sam się zaliczał do napływowej ludności, o pochodzeniu rzemieślniczym. Stanisław zapewne w wyniku podziału spadku mógł przejać nieruchomość w postaci osady w Janiszewicach ${ }^{72}$ po swej matce oraz fundusze po zmarłym rok wcześniej bracie ${ }^{73}$. Poprawa sytuacji finansowej pozwoliła mu na zabezpieczenie bytu ewentualnego potomstwa.

\section{Zatarcie pochodzenia z niższego stanu}

W metryce chrztu A. Chylińskiego z roku 1799 zostało zamazane i wytarte miejsce na około cztery wyrazy ( $2 / 3$ linijki tekstu), obok dopisane „Filus”, a nad brakujacym tekstem zapisano „Fam[atus] Joannis et Marianne Chylińskich Con[jugum] Leg[itimorum]"74. Wytarte wyrazy zapewne dokumentowały przedślubne pochodzenie A. Chylińskiego. Informację o tym usunięto zatem $z$ zapisu chrztu, by nie ciazżyła na osobie późniejszego duchownego.

Prestiż rodziny podniósł niewątpliwie sam A. Chyliński, będąc administratorem kolejnych probostw. Jako duchowny stał się przedstawicielem lokalnych elit funkcjonujacych w zasięgu parafii, których był duszpasterzem. W akcie zgonu Chylińskiego podano, że był synem obywateli miasta Lubrańca ${ }^{75}$. Jego brat Stanisław Chyliński, chcąc podnieść status rodziny, w akcie ślubu określił rodziców jako właścicieli folwarku ${ }^{76}$, a siebie jako właściciela cząstkowego zamieszkałego we wsi Janiszewice ${ }^{77}$. W akcie zgonu samego S. Chylińskiego z 1876 r. podano, że jego rodzice byli właścicielami wsi ${ }^{78}$.

\section{${ }^{72}$ Ibidem.}

${ }^{73}$ Szerzej o majatku zmarłego księdza por. P. Szkutnik, Inwentarz ruchomości z 1862 r. ks. Andrzeja Chylińskiego proboszcza parafii Męka $w$ dekanacie sieradzkim, „Archiwa, Biblioteki i Muzea Kościelne” 2020, t. CXIV, s. 371-386.

${ }^{74}$ Legalni małżonkowie.

75 APŁ, ASC Męka, sygn. 112, Akt zgonu nr 43.

${ }^{76}$ Większość folwarków w okolicach Lubrańca była własnością polskiego ziemiaństwa. Por. W. Kubiak, op. cit., s. 174.

77 APE, ASC Zduńska Wola, sygn. 96, Akt ślubu nr 29.

78 APŁ, ASC Zduńska Wola, sygn. 114, Akt zgonu nr 37. 
Wpływ na ten zapis mieli zapewne najbliżsi zmarłego, którzy znacznie „wzbogacili” tym samym przeszłość rodu.

W dokumentacji stanu cywilnego, która A. Chyliński prowadził, starał się podnieść rangę pochodzenia swoich bliskich. W aktach ślubu sióstr Franciszki z 1830 r. oraz Salomei z 1838 r. wpisał, że są one „urodzone”, co sugeruje pochodzenie szlacheckie. Podobny kwalifikator wpisał przy nazwiskach ich męźów. Określenie to pojawia się również w akcie urodzenia siostrzenicy Franciszki z 1833 r.

Dokonano również zmian we wcześniejszych metrykach łacińskich chrztu rodzeństwa Chylińskich, konkretnie: w zapisach dotyczących ich stanu społecznego. Korekty sa również dokonane $\mathrm{w}$ metrykach młodszego rodzeństwa, prawdopodobnie $z$ pominięciem tych dzieci, które nie dożyły wieku dojrzałego, stąd nie starały się o poprawę swego statusu. W metryce chrztu Stanisława z 1806 r. został zamazany kwalifikator stanowy, choć widać jego fragmenty, tj. dużą literę „H” i długie „s", co pierwotnie stanowiło określenie „Honestus”. Obok dopisano „[Dener]”, co ma zapewne oznaczać „Dominus” lub „Generosus”, czyli „pan” lub „urodzony”. W metryce chrztu Franciszki z 1809 r. określnik „Fam[atus]” przerobiono przez dopisanie liter na zapewne "Dominus”. W metryce chrztu Salomei z 1817 r. „honestor[um]” przeprawiono na najprawdopodobniej „Dominus”. W metryce chrztu z 1820 r. Józefa „Fam[atus]” przeprawiono na „Domin[us]”. Kwalifikator „Dominus” był stosowany na określenie statusu duchownych ${ }^{79}$ lub zamożnych, pełniących urzędy mieszczan ${ }^{80}$, lub też jako jeden $z$ kilku określników szlachcica.

Zmian w metrykach łacińskich dokonywano ciemnym atramentem, cienko piszacym piórem. W aktach cywilnych korekt dokonano jedynie w akcie zgonu ojca księdza z $1828 \mathrm{r}$. Wpisano tam w miejsce wytartych słów, po nazwisku jego syna Stanisława Chylińskiego, jako świadka oraz zmarłego określenie „obywatel” grubymi, ciemnymi literami, odróżniającymi się od tekstu pierwotnego. Obywatelem określano wówczas właściciela posesji w mieście lub osobę zasłużoną ${ }^{81}$.

${ }^{79}$ W.P. Wlaźlak, Dzieje kościelne Pajęczna, Pajęczno 2005, s. 208.

${ }^{80}$ Ł. Truściński, Przedstawiciel elity Grodziska Wielkopolskiego, podwójci Maciej Hanyk, w świetle jego testamentu z 1712 r., [w:] Społeczeństwo staropolskie. Seria nowa, t. V (Społeczeństwo a elity), red. A. Karpiński, Warszawa 2018, s. 274.

${ }^{81}$ W. C a b a n, Struktura społeczno-zawodowa ludności Kielc w latach 1832-1862 $w$ świetle akt stanu cywilnego, „Kieleckie Studia Historyczne” 1987, t. VI, s. 116. 
Rozpoznany i przedstawiony już status rodziców księdza powoduje, że pochodzenie Chylińskich ze stanu szlacheckiego ${ }^{82}$ budzi wątpliwości. Fałszerstwa metryk szczególnie często pojawiały się w pierwszej połowie XIX w., gdy rzady zaborcze legitymowały szlachtę, co stanowiło motywacje do korygowania/dopisywania określników stanowych w metrykach ${ }^{83}$. Chylińscy herbu Jastrzębiec legitymowali się ze szlachectwa (Antoni syn Feliksa $z$ synami) ${ }^{84}$, jednak nie ma wśród szlachty opisywanych Chylińskich z Lubrańca.

Alegata ślubu siostry księdza Franciszki nie zawierają odpisu jej chrztu, a jedynie wypis z 22 sierpnia 1829 r. metryki chrztu jej męża Leopolda Chylińskiego z 15 listopada 1802 r., który zawiera skrócone określenie statusu stanowego jego rodziców, tj. „H[onestus]”, czyli „uczciwy"85. Cholewińscy, spowinowaceni przez małżeństwo $z$ Chylińskimi, mieli zatem pochodzenie mieszczańskie. Odpis metryki łacińskiej chrztu Salomei wydany przez proboszcza parafii Lubraniec Walentego Jórkiewicza 3 stycznia 1834 r. w ogóle nie zawiera kwalifikatora określającego stan Chylińskich. Ekstrakt ten posłużył następnie jako alegata ${ }^{86}$ do aktu ślubu Salomei zawartego cztery lata później, gdzie jak wspomniano, określono ja jako „urodzona”.

Zmiana kwalifikatorów stanowych w łacińskich metrykach Chylińskich została być może dokonana w późniejszym okresie. Nie wykorzystano jej bowiem jako dowodów pochodzenia w alegatach sióstr księdza. Zmodyfikowana treść metryk mogła jednak posłużyć do wydania ekstraktów wykorzystanych do innych celów.

Osoby pochodzenia mieszczańskiego poruszające się w kręgach dworskich miały poczucie swej niższej pozycji w stratyfikacji społeczno-towarzyskiej, co niewątpliwie było powodem zabiegów o uszlachcenie ${ }^{87}$. Drogą legalną próbował pozyskać w latach 1825-1828 klejnot szlachecki, zapewne znany A. Chylińskiemu osobiście, mieszczanin $z$ Lubrańca Jan Henryk Kühn, jeden $z$ urzędników miejskich ${ }^{88}$. W staraniach o podniesienie swego statusu

${ }^{82}$ S. Zabraniak, op. cit., s. 133.

${ }^{83}$ W. Dworzaczek, Genealogia, Warszawa 1959, s. 34.

${ }^{84}$ Spis szlachty..., s. 31; Szlachta wylegitymowana..., s. 92-93.

85 APCz, ASC Przystajń, sygn. 59, k. 11.

${ }^{86}$ APCz, ASC Wąsosz, sygn. 89, k. 8.

87 J. J edlicki, Klejnot $i$ bariery społeczne: przeobrażenia szlachectwa polskiego w schyłkowym okresie feudalizmu, Warszawa 1968, s. 275.

88 Ibidem, s. 279. 
rodzina Chylińskich nie była zatem wyjątkiem. Mieszczanie, wchodząc w stan duchowny, mogli osiagnać wyższy pułap społeczny niż ten dotąd posiadany. Status ugruntowany był uposażeniem w posłudze kapłańskiej oraz prestiżem w katolickim społeczeństwie $^{89}$. Rodziło to potrzebę podniesienia rangi również najbliższych duchownego.

\section{Podsumowanie}

Andrzej Chyliński był przedstawicielem szeregowego duchowieństwa parafialnego. Nie osiagnął wyższych godności kapłańskich w administracji kościelnej, zostając pod koniec życia proboszczem i kanonikiem honorowym. Kariera księdza wpływała na losy jego rodzeństwa. W jej wyniku rodzina, pochodzaca $z$ północy diecezji kujawsko-kaliskiej, zdecydowała się przenieść do jej południowej części. Migracje wytyczały translokaty kapłana, za którym podażali krewni. Przebywanie wokół administratora parafii pozwoliło jego bliskim na kontakty $z$ przedstawicielami lokalnych elit. Poznani na miejscu kawalerowie, majacy perspektywę przynajmniej urzędniczej kariery w administracji niższego szczebla, stali się szwagrami księdza. Znajomi rodziny występowali jako chrzestni lub świadkowie. Wśród nich szlachta: posesorowie, $z$ urzędniczymi koneksjami (wojewodzic, sędzina); inteligencja: nauczyciele, urzędnicy, fachowcy; duchowni, mieszczanie-obywatele oraz niepiśmienni chłopi. Dobór niektórych chrzestnych, jak K. Blumel, może świadczyć o przejawianym lojalizmie w tym prowincjonalnym ziemiańsko-urzędniczym środowisku. Franciszka poślubiła L. Cholewińskiego, który był archiwista komisji wojewódzkiej, a potem wójtem gminy. Salomea poślubiła T. Walewskiego, który był strażnikiem celnym, a z czasem stał się właścicielem osady na wsi. Miejsce pracy ich brata - księdza zadecydowało o wyborze miejsca zamieszkania i partnerów życiowych, a także pozwoliło na awans społeczny zwiazany ze zgromadzeniem odpowiednich środków na zakup nieruchomości.

89 D. O1szewski, Struktura społeczna duchowieństwa diecezji kielecko-krakowskiej (1835-1864), [w:] Społeczeństwo polskie XVIII i XIX wielu. Studia o uwarstwieniu i ruchliwości społecznej, t. VI, red. J. Leskiewiczowa, Warszawa 1974, s. 132; P. Szkutnik, Duchowieństwo dekanatu szadkowskiego $w$ roku 1835 , „Biuletyn Szadkowski” 2007, t. VII, s. 50. 
Siostry księdza niejednokrotnie dopiero po dłuższym czasie od urodzenia chrzciły dzieci, nadając im więcej niż jedno imię, co było zwyczajem sfer wyższych, odróżniającym się od praktyki chrzczenia dzieci chłopskich ${ }^{90}$. Dokumentacja metrykalna dowodzi drobnomieszczańskiego pochodzenia rodziny, w tym przedślubnego samego duchownego. W późniejszej dokumentacji rodzeństwo księdza jest określane kwalifikatorem stanowym „urodzony”, jednak akt ślubu rodziców księdza ujawnia ich niższa pozycję - „honestus”, czyli „uczciwy”. Ojciec księdza był rzemieślnikiem, stąd można przyjąć, że należał do drobnomieszczaństwa małego miasta, jakim był Lubraniec. Duchowny niewątpliwie wspierał swoją rodzinę, która $z$ czasem usamodzielniła się finansowo, gdy administrował w Męce koło Sieradza. Brat osiadł w pobliskich Janiszewicach koło Zduńskiej Woli, a siostry w okolicach Wielunia i Częstochowy. Spadek, który otrzymali po śmierci brata, niewątpliwie poprawił również ich kondycję finansowa, stanowiąc ostatnie pośmiertne wsparcie duchownego dla najbliższych.

Niniejsze „studium przypadku” jedynie sygnalizuje możliwości badawcze źródeł w zakresie ustalenia powiązań rodzinnych XIX-wiecznego duchownego parafialnego oraz prób wyciagania wniosków wynikających z zależności między statusem duchownego i droga jego kariery a losami jego najbliższych.

\section{Bibliografia}

\section{$\dot{Z}_{\text {RÓDEA ARCHIWALNE }}$}

Archiwum Archidiecezji Częstochowskiej [AACz]

sygn. KM 1646, KM 4639, KM 4716, KM 4717.

Archiwum Diecezjalne we Włocławku [ADWł]

sygn. KM par. Lubraniec 2, 2a, 4, 14, 17, 19, 24.

Archiwum Państwowe w Częstochowie [APCz]

Akta stanu cywilnego Przystajń, sygn. 59.

Akta stanu cywilnego Truskolasy, sygn. 72, 76, 78, 82, 84, 104.

Akta stanu cywilnego Wąsosz, sygn. 53, 89.

${ }^{90}$ L. Dacewicz, Uwarunkowania socjalno-kulturowe nadawania imion podwójnych w Dekanacie Białystok w II połowie XIX wieku, „Studia Wschodniosłowiańskie" 2017, t. XVII, s. 170-172, 182. 
Archiwum Państwowe w Łodzi [APŁ]

Akta stanu cywilnego Męka, sygn. 112.

Akta stanu cywilnego Czastary, sygn. 90, 93, 95, 98, 102, 105, 109.

Akta stanu cywilnego Wieluń, sygn. 110.

Akta stanu cywilnego Zadzim, sygn. 68.

Akta stanu cywilnego Zduńska Wola, sygn. 96, 114.

Archiwum Państwowe w Łodzi - Oddział w Sieradzu [APŁoS]

Akta notariusza J. Sikorskiego w Szadku, sygn. 8.

Archiwum Państwowe w Toruniu - Oddział we Włocławku [APToW]

Akta stanu cywilnego Lubraniec, sygn. 1, 9, 19, 27.

\section{ŹRÓDEA DRUKOWANE}

Encyklopedja kościelna podług teologicznej encyklopedji Wetzera $i$ Weltego z licznemi jej dopełnieniami przy wspótpracownictwie kilkunastu duchownych $i$ świeckich osób, wyd. M. Nowodworski, t. X, Warszawa 1877.

Ordo divini offici ad usum dioecesis Vladislaviensis seu Calissiensis pro anno domini $1862 \ldots$, Warszawa [1861].

Ordo divini offici ad usum universi cleri saecularis dioecesis Vladislaviensis seu Calissiensis pro anno bissextili MDCCCXX..., Warszawa [1819].

Spis szlachty Królestwa Polskiego z dodaniem krótkiej informacyi o dowodach szlachectwa, Warszawa 1851.

Szlachta wylegitymowana w Królestwie Polskim w latach 1836-1861, oprac. E. Sęczys, Warszawa 2000.

Złota ksiega szlachty polskiej, oprac. T. Żychliński, R. I-V, Poznań 1879-1883.

\section{OpRacowania}

Caban W., Struktura społeczno-zawodowa ludności Kielc w latach 1832-1862 $w$ świetle akt stanu cywilnego, „Kieleckie Studia Historyczne” 1987, t. VI, s. 113-132.

Dacewicz L., Uwarunkowania socjalno-kulturowe nadawania imion podwójnych $w$ Dekanacie Białystok w II połowie XIX wieku, „Studia Wschodniosłowiańskie" 2017, t. XVII, s. 169-186.

Dworzaczek W., Genealogia, Warszawa 1959.

Jedlicki J., Klejnot i bariery społeczne: przeobrażenia szlachectwa polskiego w schyłkowym okresie feudalizmu, Warszawa 1968.

Kobierecki M., Walewscy herbu Kolumna w XVII-XVIII wieku. Genealogia. Majętności. Działalność publiczna, Łódź 2008.

Kubiak W., Dzieje Lubrańca, Torun 2005.

Kujawski W., Kościelne dzieje Sieradza, Włocławek 1998. 
Lewalski K., Odsłony codzienności. Rzymskokatolickie duchowieństwo parafialne na prowincji Królestwa Polskiego na przełomie XIX $i$ XX wieku. Wybrane zagadnienia, Gdańsk 2019.

Muznerowski S., Lubraniec (monografia), Włocławek 1910.

Olszewski D., Struktura społeczna duchowieństwa diecezji kielecko-krakowskiej (1835-1864), [w:] Społeczeństwo polskie XVIII i XIX wielu. Studia o uwarstwieniu i ruchliwości społecznej, t. VI, red. J. Leskiewiczowa, Warszawa 1974, s. 129-183.

Szkutnik P., Duchowieństwo dekanatu szadkowskiego w roku 1835, „Biuletyn Szadkowski" 2007, t. VII, s. 27-60.

Szkutnik P., Inwentarz ruchomości z 1862 r. ks. Andrzeja Chylińskiego proboszcza parafii Męka w dekanacie sieradzkim, „Archiwa, Biblioteki i Muzea Kościelne” 2020, t. CXIV, s. 371-386.

Truściński Ł., Przedstawiciel elity Grodziska Wielkopolskiego, podwójci Maciej Ha$n y k, w$ świetle jego testamentu z 1712 r., [w:] Społeczeństwo staropolskie. Seria nowa, t. V (Społeczeństwo a elity), red. A. Karpiński, Warszawa 2018, s. 263-278.

Wlaźlak W.P., Dzieje kościelne Pajęczna, Pajęczno 2005.

Wlaźlak W.P., Parafia Przenajświętszej Trójcy w Przystajni, „Rocznik Towarzystwa Genealogicznego Ziemi Częstochowskiej” 2015-2016, t. VII-VIII, s. 101-102.

Wlaźlak W.P., Parafia św. Mikołaja Biskupa i Wyznawcy w Wilkowiecku, „Rocznik Towarzystwa Genealogicznego Ziemi Częstochowskiej” 2015-2016, t. VII-VIII, s. $127-128$.

Zabraniak S., Między Warta a Liswartą. Z dziejów parafii Wąsosz (do 2015 r.), Częstochowa 2015.

NOTKA O AUTORZE:

Dr Piotr Szkutnik - adiunkt w Katedrze Historii Historiografii i Nauk Pomocniczych Historii na Wydziale Filozoficzno-Historycznym Uniwersytetu Łódzkiego.

Zainteresowania naukowe: genealogia, historia regionalna, archiwistyka, edytorstwo, demografia historyczna, historia Kościoła katolickiego, prozopografia, biografistyka, źródła audiowizualne.

ఐ piotr.szkutnik@uni.lodz.pl 